\title{
EFFECT OF POLE SIZE ON PRESERVATIVE PENETRATION AND RETENTION IN AIR-DRIED UGANDAN GROWN EUCALYPT UTILITY POLES
}

\author{
Paul Mugabi ${ }^{1, \diamond}$, James Thembo ${ }^{1}$
}

\begin{abstract}
Treated wooden utility poles, from trees such as eucalypts, are the most commonly used for telephone and electricity transmission lines in Uganda. In the last decade, however, frequent failure of wooden poles in service has been reported, likely due to the preservative chemical, wood used or the treatment process. The objective of this study was to assess the creosote preservative penetration and retention in eucalypt wood. A total of 126 Eucalyptus grandis poles i.e. 42 poles for each size category, with an average moisture content of below fibre saturation point $(28 \%)$ were treated in different charges depending on their size. In length, poles used were 9,11 and $14 \mathrm{~m}$. Every charge consisted of poles within the same size category. The Full Cell pressure method was used to treat the different charges with creosote preservative. For all the charges the same treatment schedule was maintained. Creosote penetration was highest in $14 \mathrm{~m}$ poles $(20,5 \mathrm{~mm})$ and lowest in $9 \mathrm{~m}$ poles $(18,4 \mathrm{~mm})$, Creosote retention was also highest in $14 \mathrm{~m}$ poles $\left(193 \mathrm{~kg} . \mathrm{m}^{-3}\right)$, but lowest in $11 \mathrm{~m}$ poles $\left(162 \mathrm{~kg} . \mathrm{m}^{-3}\right)$. Irrespective of differences in level of penetration and retention among the various pole sizes, all the poles acquired more than the required standard minimum level of penetration and retention i.e. $15 \mathrm{~mm}$ and $115 \mathrm{~kg} . \mathrm{m}^{-3}$ respectively. However, for all the pole sizes, creosote penetration was less than the sapwood depth. The current treatment schedule seems better suited for the larger poles of $14 \mathrm{~m}$ than the 9 and $11 \mathrm{~m}$. For better treatment, it is recommended that smaller poles i.e. $9 \mathrm{~m}$ and $11 \mathrm{~m}$ should be treated for a longer period than $14 \mathrm{~m}$ poles since they tend to have lager sapwood. The minimum basis of $15 \mathrm{~mm}$ penetration should be increased to at least cover the entire pole sapwood depth.
\end{abstract}

Keywords: Creosote, Eucalyptus grandis, transmission poles, treated wood, wood preservation.

\section{INTRODUCTION}

Preservative treatment greatly increases the service life of wood structures (Lebow et al. 2004), reducing replacement costs and allowing more efficient use of forest resources. Preservation of utility poles has expanded rapidly in Uganda in the last decade to cater for the demand created by extensive expansion of the electric grid to many rural areas. In addition, treated poles are also exported to South Sudan, Tanzania and other countries in the region. Eucalyptus species are the commonly used and these are mainly treated with coal tar creosote although Copper Chrome Arsenate (CCA) preservative is also increasingly used lately. The treatment methods used involve pressure/vacuum processes to ensure good preservative penetration and retention. However, of recent, frequent premature failures of treated poles in service have been reported in different parts of the country leading to financial losses and risking lives in the case of electric transmission lines. This has raised questions regarding the wood material used, suitability of the preservative chemicals, and the methods of treatment.

Previously it was mostly Eucalyptus grandis from government forests that was used for utility 
poles, however, of late poles are mainly sourced from private forests located in different agro-ecological zones around the country. One of the most common eucalypts currently grown on these private farms are the fast growing hybrid clones imported from South Africa. Cookson (2000) noted that as the material changes, utilization of faster growing species with lower natural durability and higher proportions of sapwood increases the need for suitable preservation. Eucalypts generally have treatable sapwood but the heartwood mostly cannot be treated easily (Cookson 2000). The different utility pole sizes in Uganda include 9, 10,11,12,14,15, 16 and 18m in length depending on the intended use. Poles of different sizes are expected to have varying sapwood sizes which should be fully treated.

Currently, the same schedule is used by the main pole treatment company, Uganda Electricity Distribution Company Limited (UEDCL) in treating poles with creosote irrespective of their sizes i.e. varying pole length and diameter. The schedule involves an initial vacuum of $50 \mathrm{kPa}$ for 15 minutes, flooding cylinder with chemical for 20 minutes, applying 1260kPa pressure for 2 hours and 40 minutes, emptying cylinder takes 15 minutes, and the final vacuum of $30 \mathrm{kPa}$ for 10 minutes. Using the same treatment schedule might lead to either insufficient treatment for poles with larger sapwood or wastage of resources for poles with smaller sapwood. There has been also a general feeling that the creosote being used could be adulterated leading to insufficient treatment of poles.

The objectives of this study were (i) to assess the creosote penetration in eucalyptus poles of sizes $9 \mathrm{~m}, 11 \mathrm{~m}$ and $14 \mathrm{~m}$; (ii) to determine the creosote retention in the poles; and (iii) to investigate the relationship between preservative penetration and retention among the different sizes of poles.

\section{MATERIALS AND METHODS}

\section{Timber}

A total of 126 poles i.e. 42 poles for each size; 9,11 , and $14 \mathrm{~m}$ having an average moisture content below $28 \%$ were treated in different charges depending on their lengths, using creosote preservative. The moisture content was determined using a moisture meter which was measured at a depth of $25,4 \mathrm{~mm}$ ( 1 inch) into the wood. Exactly the same treatment schedule was used for all the charges (see introduction).

\section{Sampling and measurements}

\section{Determination of creosote penetration}

Three wood borings per pole were extracted $1,5 \mathrm{~m}$ from the butt end (Theoretical Ground Line), at mid-length and $1,5 \mathrm{~m}$ from the top end using a wood borer. The borer was drilled $25,4 \mathrm{~mm}$ ( $1 \mathrm{inch}$ ) deep into the pole. The borings were spread on a graduated plate where the black part covered by creosote oil was observed and its length measured.

\section{Determination of creosote retention}

Using the same borings that were used to determine creosote penetration $6,45 \mathrm{~mm}(0,25 \mathrm{inch})$ part of the boring was cut and discarded. The remaining $19 \mathrm{~mm}(0,75 \mathrm{inch})$ of the boring was weighed and recorded. The weighed borings were placed in a syphon-type extraction cup held in the neck of a flask in which toluene was boiled. The vapors of toluene and water passed into an offset condenser that was fitted at the bottom with a calibrated water trap. The condensed water settled to the bottom of the trap and the lighter toluene formed a layer above it. The condensed toluene flowed back over the borings in the flask and gradually extracted the oil. Extraction continued until the solvent was colorless and no water dropped into the trap. The volume of water was read, and the borings were removed and placed in an oven to evaporate the toluene. The borings were then weighed. The difference between the initial and final weights of the borings was corrected for the water collected, to determine the amount of oil 
removed. It was assumed that $1 \mathrm{~mm}$ of water weighed $1 \mathrm{~g}$ (Baechler 1959).

\section{Data analysis}

Data analyses were carried out using SPSS version 17 and Minitab14. Since data were normally distributed, parametric tests were used. To compare differences in creosote penetration and retention with pole sizes, one-way analysis of variance (ANOVA) was used. Univariate analysis was used to show the variation of creosote along the pole length.

\section{RESULTS}

\section{General}

The average pole diameter, sapwood depth and moisture content for the poles studied are shown in Table 1. Nine meter ( $9 \mathrm{~m})$ poles had the largest sapwood (butt and top) and highest mid length moisture content while $14 \mathrm{~m}$ poles had the smallest sapwood (top).

Table 1. Average pole diameter, sapwood depth and moisture content for the poles.

\begin{tabular}{|c|c|c|c|c|c|}
\hline $\begin{array}{c}\text { Pole Length } \\
\mathbf{( m )}\end{array}$ & $\begin{array}{c}\text { Butt end Diameter } \\
\mathbf{( m m )}\end{array}$ & $\begin{array}{c}\text { Butt end sapwood } \\
\text { depth } \mathbf{( m m )}\end{array}$ & $\begin{array}{c}\text { Top } \\
\text { diameter } \\
\mathbf{( m m})\end{array}$ & $\begin{array}{c}\text { Top } \\
\text { sapwood } \\
\text { depth (mm) }\end{array}$ & $\begin{array}{c}\text { Mid length } \\
\text { moisture } \\
\text { content }(\mathbf{\%})\end{array}$ \\
\hline 9 & 196 & 28,8 & 120 & 25,6 & 25,4 \\
\hline 11 & 261 & 27,4 & 180 & 24,6 & 23,7 \\
\hline 14 & 323 & 27,8 & 236 & 20,8 & 24,2 \\
\hline
\end{tabular}

\section{Creosote penetration and retention}

The mean creosote penetration and retention in the various sizes of poles is shown in Table 2. Creosote penetration was highest in $14 \mathrm{~m}$ and lowest in $9 \mathrm{~m}$ (Table 2) while retention was highest in size $14 \mathrm{~m}$ and lowest in $11 \mathrm{~m}$ poles (Table 2). It can be observed from Table 1 and Table 2 that the sapwood of all the pole sizes was not fully treated.

Table 2. Mean creosote penetration and retention.

\begin{tabular}{|l|l|l|l|l|}
\hline Pole length (m) & \multicolumn{2}{|l|}{ Creosote penetration $\mathbf{( m m )}$} & Creosote retention $\left(\mathbf{k g} \cdot \mathbf{m}^{-\mathbf{3}}\right)$ \\
\hline & Mean & $\begin{array}{l}\text { Standard } \\
\text { Deviation }\end{array}$ & Mean & $\begin{array}{l}\text { Standard } \\
\text { Deviation }\end{array}$ \\
\hline $9 \mathrm{~m}$ & $18,4 a$ & 2,73 & $174,6 a$ & 43,98 \\
\hline $11 \mathrm{~m}$ & $18,5 a$ & 1,77 & $161,9 a$ & 22,65 \\
\hline $14 \mathrm{~m}$ & $20,5 b$ & 2,19 & $193,0 b$ & 41,89 \\
\hline \multicolumn{4}{|l}{ Same letter $=$ No significant difference, Different letters = There is a significant difference. } \\
\hline
\end{tabular}

One-way ANOVA showed significant differences $(p<0,05)$ in penetration among the pole sizes. Significant differences $(p<0,05)$ in creosote retention were also observed among the different pole sizes. Post Hoc tests confirmed retention being significantly $(\mathrm{p}<0,05)$ higher in $14 \mathrm{~m}$ than both 9 and $11 \mathrm{~m}$ poles (Table 2). However, differences in creosote penetration and retention in the 9 and $11 \mathrm{~m}$ poles were not significant $(\mathrm{p}>0,05)$.

\section{Variation of preservative penetration along the pole length}

Univariate Analysis showed that the bottom part had a significantly $(\mathrm{p}<0,05)$ higher creosote 
penetration compared to mid length and top parts. Post hoc LSD test confirmed that creosote penetration at the bottom was higher compared to the midpoint and the top positions (Figure 1).

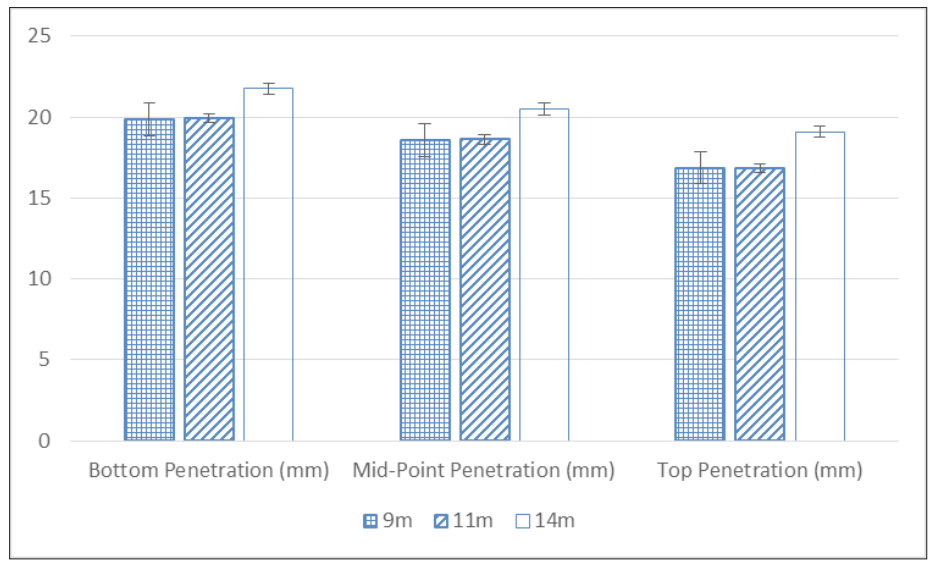

Figure 1. Creosote penetration along the pole length.

\section{Relationship between Creosote Penetration and Retention}

A strong, positive correlation was observed between creosote penetration and retention $(\mathrm{r}=0,66 ; \mathrm{p}<0,05)$ as showed in Figure 2 .
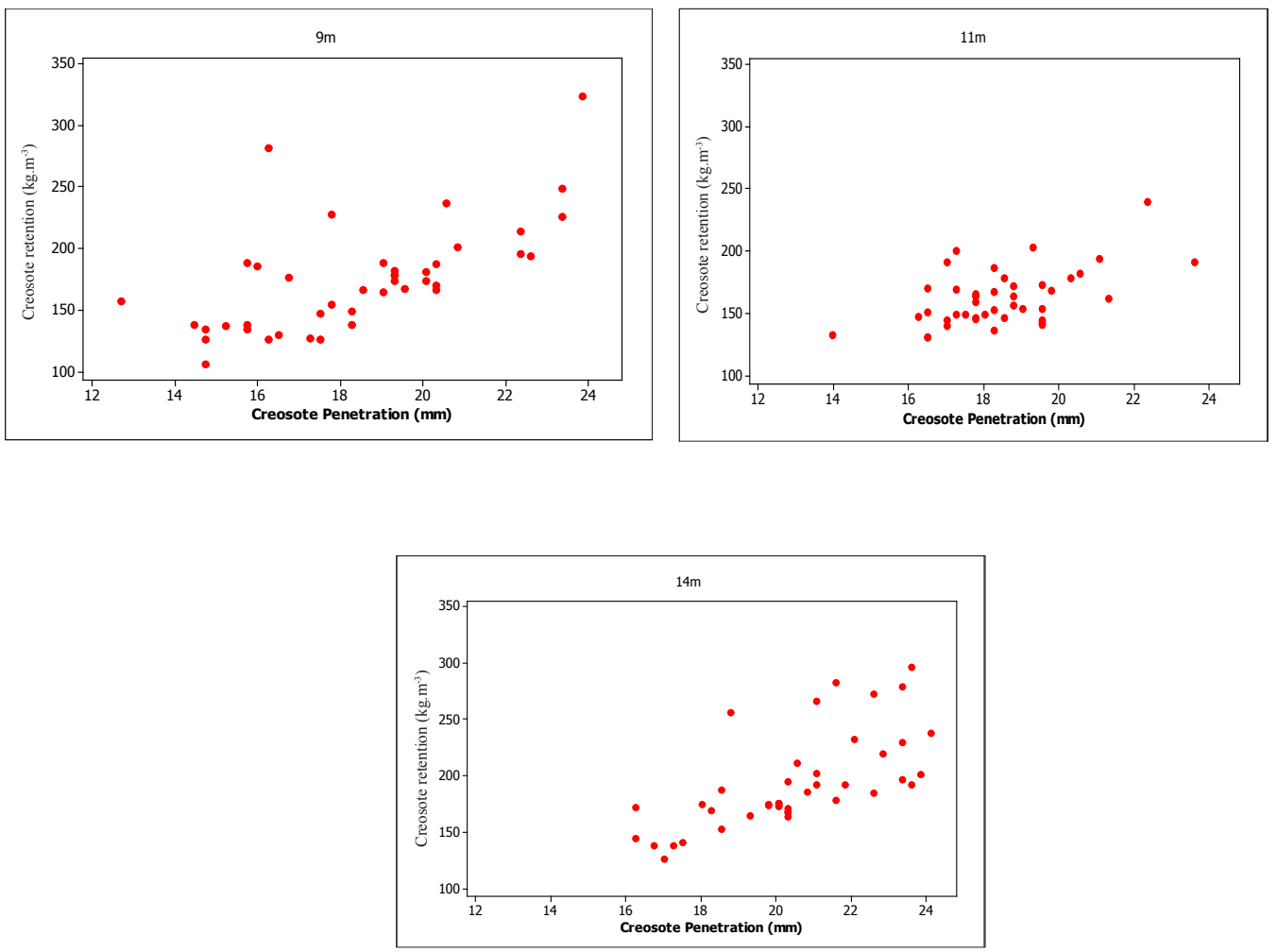

Figure 2. Interactive scatter plots for creosote penetration and retention for the three pole sizes. 


\section{DISCUSSION}

\section{Differences in creosote penetration}

The higher creosote penetration in $14 \mathrm{~m}$ poles compared to the other sizes could be due to the relatively lower moisture content at the time of treatment (Table 1). Creosote penetration was higher in the bottom parts for all the pole sizes perhaps due to the larger sapwood depth in all poles. Sapwood cells are highly porous compared to heartwood cells hence take in the preservative more easily. Rice and Onofrio (1996) noted the permeability of wood may be influenced by habitat, heart-sapwood sections as well as the chemical constituents. A higher penetration is desired to provide adequate protection against biological agents (Blew and Davidson 1971) especially since the bottom part of the pole is usually inserted in the ground and covered with soil.

\section{Differences in creosote retention}

The higher creosote retention observed in $14 \mathrm{~m}$ poles compared to the other sizes could be due to the relatively lower moisture content at the time of treatment (Table 1). It is possible that since $14 \mathrm{~m}$ poles had larger diameter compared to the other sizes, they were also older with higher density hence the higher creosote retention. High retention is required for service conditions where the hazard is increased such as ground contact. In any case the average net retention should not be less than $115 \mathrm{~kg} . \mathrm{m}-$ ${ }^{3}$ for proper protection against biological agents (PIESA 1001:2004 and EAS 322:2002).

\section{Relationship between Penetration and Retention}

Penetration and retention requirements are equally important in determining the quality of preservative treatment. Penetration levels vary widely, even in pressure-treated material (Blew \& Davidson 1971). In most species, heartwood is more difficult to penetrate than sapwood. In addition, species differ greatly in the degree to which their heartwood may be penetrated. In this study, both creosote penetration and retention proportionately increased with a strong positive correlation coefficient. This justifies why eucalyptus is used for heavy duty transmission lines since it requires both higher preservative retention and penetration. It should be noted, however, that all pole sizes in the study met the minimum penetration $(15 \mathrm{~mm})$ and retention $\left(115 \mathrm{~kg} \cdot \mathrm{m}^{-3}\right)$ requirements (EAS 322:2002).

\section{CONCLUSIONS AND RECOMMENDATIONS}

It was concluded that:

Creosote penetration and retention were highest in $14 \mathrm{~m}$ poles $\left(20,5 \mathrm{~mm}\right.$ and $\left.193 \mathrm{~kg} \cdot \mathrm{m}^{-3}\right)$ while penetration was lowest in $9 \mathrm{~m}$ poles $(18,4 \mathrm{~mm})$ and retention was lowest in $11 \mathrm{~m}$ poles $\left(162 \mathrm{~kg} \cdot \mathrm{m}^{-3}\right)$.

For all the pole sizes, creosote penetration was less than the sapwood depth.

Creosote penetration and retention were strongly and positively correlated, and the relationship was strongest in the $14 \mathrm{~m}$ poles.

Irrespective of the differences in level of penetration and retention among the various pole sizes, all the poles acquired more than the required minimum standard level of penetration and retention.

The current treatment schedule seems better suited for the larger poles $(14 \mathrm{~m})$ than the 9 and $11 \mathrm{~m}$ poles. 
It is recommended that:

Treatment schedules be varied with pole size category for better treatment. Smaller poles i.e. $9 \mathrm{~m}$ and $11 \mathrm{~m}$ should be treated for a longer period than $14 \mathrm{~m}$ poles since they tend to have lager sapwood.

Measurements of sapwood/heartwood proportions be ascertained before treatment and related to creosote penetration and retention to ensure critical pole parts are sufficiently treated.

Since the average sapwood for the three pole sizes was approximately $26 \mathrm{~mm}$ (Table 1 ), the $15 \mathrm{~mm}$ minimum penetration basis by the Uganda Electricity Distribution Company Limited (UEDCL) is insufficient and should, therefore, be increased.

\section{ACKNOWLEDGEMENTS}

We acknowledge the support given by the Uganda Electricity Distribution Company Limited (UEDCL) during the course of this study.

\section{REFERENCES}

Baechler, R.H. 1959. Determining Preservative Retention in Piling by the assay of Borings. Forest Department Laboratory: Madison.

Blew, J.O.; Davidson, H.L. 1971. Preservative retentions and penetration in the treatment of white fir. Proceedings of American Wood Preservers' Association 67: 204-221.

Cookson, L.J. 2000. The preservation of eucalypts. In: The future of eucalypts for wood products. Proceedings IUFRO conference; 19-24 March, 2000; Launceston, Tasmania. IUFRO. 248-255.

EAS 323:2002. 2002. Specification for wood preservation by means of pressure creosoting. EAS 323:2002. East African Standard, $1^{\text {st }}$ edition.

Lebow, S.; Cooper, P; Lebow, P. 2004. Variability in Evaluating Environmental Impacts of Treated Wood. Proceedings of The Environmental Impacts of Preservative-Treated Wood Conference. Orlando, Florida. February 2004.

PIESA 1001:2004. 2004. Specifications for treatment of Wood Poles, Cross-arms and Spacer Blocks. The Power Institute for East and Southern Africa.

Rice, R. W.; Onofrio, M. 1996. Longitudinal gas permeability measurements from Eastern white pine, Red spruce and Balsam fir. Wood and Fiber science 28 (3): 301-308. 